\title{
A revision of Atlantic Asteropus Sollas, 1888 (Demospongiae), including a description of three new species, and with a review of the family Coppatiidae Topsent, 1898
}

\author{
Eduardo Hajdu 1,2 \& Rob W.M. van Soest ${ }^{2}$ \\ ${ }^{1}$ Laboratório de Poríferos, Departamento de Zoologia, Instituto de Biologia, Universidade Federal do \\ Rio de Janeiro, Cep. 21941 Cidade Universitária, Rio de Janeiro, Brasil; ${ }^{2}$ Institute of Taxonomic \\ Zoology, University of Amsterdam, P.O. Box 4766, 1009 AT Amsterdam, The Netherlands
}

Keywords: taxonomy, Asteropus, Coppatiidae, Demospongiae

\begin{abstract}
Various records of $A$. simplex Carter, 1879 from the Atlantic are assigned to three new species of the sponge genus Asteropus Sollas, 1888, viz.: A. brasiliensis sp. n., A. vasiformis sp. n., and $A$. niger sp. n., whereas $A$. simplex s.s. is restricted to the IndoPacific. A worldwide study of Asteropus specimens resulted in the conclusion that two species groups exist, namely "simplex"like species (with true sanidasters), and "sarasinorum"-like species (with spiny microrhabds), as previously observed by Bergquist $(1965,1968)$. A newly discovered microsclere complement of trichodragmata in the first group strengthens the need for generic distinction of both lineages, and accordingly the name Melophlus Thiele, 1899 is reinstated for the "sarasinorum" species group. A key to the West Atlantic species of Asteropus is provided. The family allocation of Asteropus and associated genera in the Coppatiidae Topsent, 1898 is discussed, with the conclusion that the family is undoubtedly a polyphyletic assemblage related to various astrophorid groups (Hooper, 1986; Van Soest, 1991).
\end{abstract}

\section{Resumo}

As citações de Asteropus simplex para o Atlântico são referidas a três novas espécies de Asteropus, viz.: $A$. brasiliensis sp. n., $A$. vasiformis sp. n. e $A$. niger sp. n.; $A$. simplex s.s. fica restrito ao Indo-Pacífico. $O$ estudo de espécimens de Asteropus de todo o mundo resultou na conclusão de que dois grupos de espécies estão envolvidos, espécies tipo-"simplex" (com sanidasters verdadeiras) e espécies tipo-"sarasinorum" (com microrabdes espinadas), como já notado por Bergquist (1965, 1968). Um recente descoberto complemento de tricodragmas no primeiro grupo reforça a necessidade de distinção genérica de ambas linhagens e assim sendo, o nome Melophlus Thiele, 1899 é recuperado para o grupo de espécies tipo-"sarasinorum". Uma chave de identificação para as espécies do Atlântico Ocidental é for- necida. A associação de Asteropus e outros gẽneros relacionados à família Coppatiidae Topsent, 1898 é discutida, levando à conclusão de que a familia é certamente um taxon polifilético relacionado a vários grupos de Astrophorida (Hooper, 1986; Van Soest, 1991).

\section{Introduction}

Examination of several western Atlantic specimens recorded as Asteropus simplex Carter, 1879 (cf. Boury-Esnault, 1973; Van Soest \& Stentoft, 1988; Muricy et al., 1991), as well as undescribed material, revealed the existence of several distinct species which all showed differences with $A$. simplex sensu Carter (1879). It is the purpose of this paper to describe and compare these new species.

As revealed by the present study, many Asteropus specimens share a previously unknown complement of trichodragmata, linking them to the genus Holoxea Topsent, 1892 and focussing our attention on distinction among genera in the family to which Asteropus is usually attributed. A further purpose of this paper is to contribute to the discussion of the classification of this group. A brief historical survey is necessary to outline the problem.

Topsent (1898) erected the family Coppatiidae (replacing Epipolasidae Sollas, 1888, which does not fulfill the requirement for family names; the name Epipolasidae was never fixed by application of a type genus name - Article 35, ICZN), for sponges belonging to rather distinct lineages: Topsentia Berg, 1899 (as Anisoxya Topsent, 1898) and 
Spongosorites Topsent, 1896 (both Halichondrida); Hemiasterella Carter, 1879 and Tethya Lamarck, 1814 (as Magog Sollas, 1888) (possibly Hadromerida); Jaspis Gray, 1867 (as Coppatias Sollas, 1888) and Asteropus Sollas, 1888 (probably Astrophorida). He stressed the possession of euasters and diactinal megascleres, and absence of triaenes, as the shared derived characters for this group. Later, Hentschel (1923) added the genera Cryptotethya Dendy, 1905 (= Tethya), Diastra Row, 1911 (a possible synonym of Stelletta Schmidt, 1862), and Paracordyla Hallmann, 1912 (= Scolopes Sollas, 1888). This assemblage has not been accepted as one of monophyletic origin by modern authors due to major differences in skeletal arrangement, as well as distinct spicule types, habit, and chemical constituents.

However, there is a group of genera currently accepted by some authors (e.g. Bergquist, 1968) as comprising the Coppatiidae. They share a spicular complement of diactinal megascleres arranged in a confused/radial choanosomal pattern and asterose microscleres. The ectosomal skeleton is a tangential layer of megascleres (as opposed to the tangential microscleres found in certain astrophorid genera like Penares Gray, 1867 and Erylus Gray, 1867). This group includes the genera Jaspis Gray, 1867, Asteropus Sollas, 1888, Holoxea Topsent, 1892, Melophlus Thiele, 1899, and Lamellomorpha Bergquist, 1968. In this group, Neamphius De Laubenfels, 1953 also seems to fit, although this is unconfirmed due to its possession of amphiasters. The Coppatiidae are here considered to be close to the Astrophorida, based on the observation that reduced radiality, rarity/absence of triaenes, and presence of tangential microxea is also found in some Astrophorida of the family Ancorinidae. A similar point of view, though much reduced in scope, was expressed by Burton \& Rao (1932), Bergquist (1968) and Bergquist \& Hartman (1969).

The family allocation of Asteropus in the Coppatiidae was formally challenged by Dendy (1916a) and, more recently, also by Van Soest \& Stentoft (1988). Bergquist (pers. comm.) also expressed doubts over it. These authors suggest that Asteropus and possibly also other coppatiid genera are simply Ancorinidae without triaenes, related to var- ious ancorinid genera possessing triaenes. In the course of this paper various genera of Coppatiidae are compared to various Ancorinidae in order to arrive at the proper family allocation of Asteropus.

\section{Material and methods}

The Brazilian Asteropus specimens are deposited in the collection of Porifera in the Universidade Federal do Rio de Janeiro (UFRJ POR). They were collected during an ecological survey of the sponge fauna of Arraial do Cabo, southeastern Brazil (Muricy, 1989; Muricy et al., 1991, recorded as $A$. simplex). Data about specimens quoted in "Material examined" are as complete as possible.

A fragment of the holotype of $\boldsymbol{A}$. brasiliensis sp. $\mathbf{n}$. is deposited in the collections of the Zoölogisch Museum Amsterdam (ZMA), number POR 9761. Additional material from the collections of ZMA, the Muséum National d'Histoire Naturelle, Paris (MNHN), the Natural History Museum, London (BMNH), and the United States National Museum, Washington (USNM) was studied for comparison. Section and spicule mounts for light microscopic study were made according to methods described by Rützler (1978). SEM preparations of spicules were made as described by Buizer \& Van Soest (1977). "In toto" SEM preparations were treated with $20 \% \mathrm{HNO}_{3}$ for 3-12 h, after which they were coated with a thin layer of gold.

\section{Systematic descriptions}

\section{Genus Asteropus Sollas, 1888}

Type species: Stellettinopsis simplex Carter, 1879, by monotypy (Article 68d, ICZN).

Diagnosis. - Ancorinidae without triaenes, with a tangential ectosomal skeleton of megascleres; with oxyasters and sanidasters, to which trichodragmata may be added.

\section{Asteropus brasiliensis sp. $\mathrm{n}$.}

(Fig. 1 a-d; Pl. I A-F)

Asteropus simplex sensu Boury-Esnault, 1973: 273, text-fig. 14; Hechtel, 1976: 249 and 252; Muricy et al., 1991: 1187, 1190 (non Stellettinopsis simplex Carter, 1879).

Material examined. - Holotype: UFRJ POR 3022, Pedra Vermelha (22 $59.17^{\prime} \mathrm{S} 41^{\circ} 59.57^{\prime} \mathrm{W}$; Arraial do Cabo, southeastern Brazil), $3 \mathrm{~m}$ depth. 


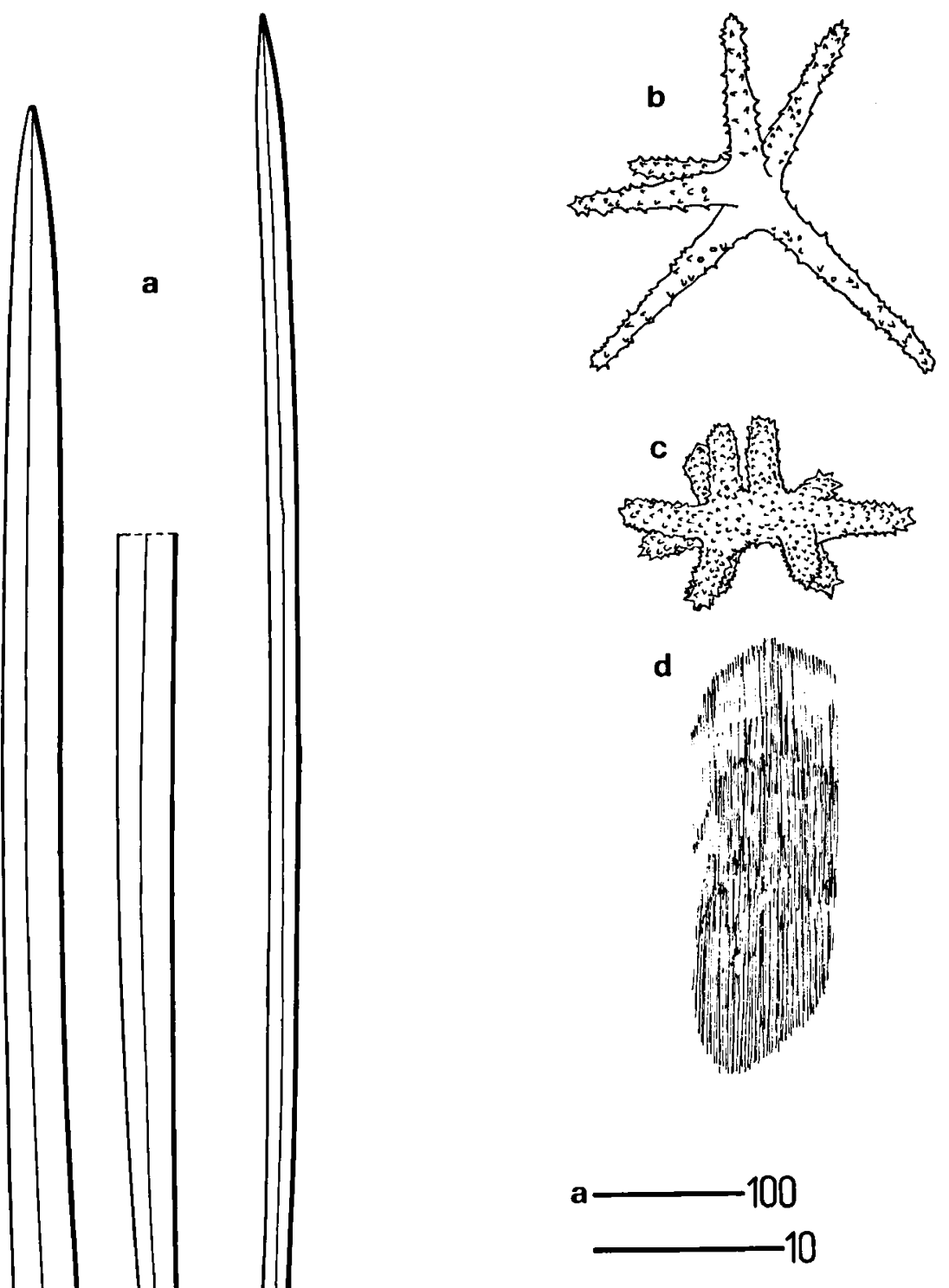

Paratypes: UFR J POR 2575, Praia dos Anjos, $3 \mathrm{~m}$ depth, coll. E. Hajdu, 09/V/1987; UFR J POR 2814, Praia do Forno, $4.5 \mathrm{~m}$ depth, 07/IIl/1988; UFRJ POR 2889, 2908, 2913, and 2915a, all four from Pedra Vermelha, 6.5-7 m depth, 10/V/1987; UFRJ POR 2974, Pedra Vermelha, $6 \mathrm{~m}$ depth, coll. G. Muricy, 24/VIII/1987; UFRJ POR 3027, Pedra Vermelha, $3 \mathrm{~m}$ depth; UFRJ POR 3038, Pedra Vermelha, $5 \mathrm{~m}$ depth, coll. G. Muricy, 08/III/1988.

Fig. 1. Asteropus brasiliensis sp. n., spicules: a, oxeas; b, oxyaster; c, sanidaster; d, trichodragma. Scales are in $\mu \mathrm{m}$.

Additional material: UFRJ POR 3371 (fragment from MNHN NBE 1025), Pernambuco State coast $\left(08^{\circ} 19^{\prime} \mathrm{S}\right.$ 34³9' W), 75 m depth, "Calypso"' 1961/62 (Boury-Esnault, 1973; recorded as A. simplex).

Description. - The sponge is cushion-shaped to subglobose. Specimens attain a size of $25 \mathrm{~cm}^{2}$ by 

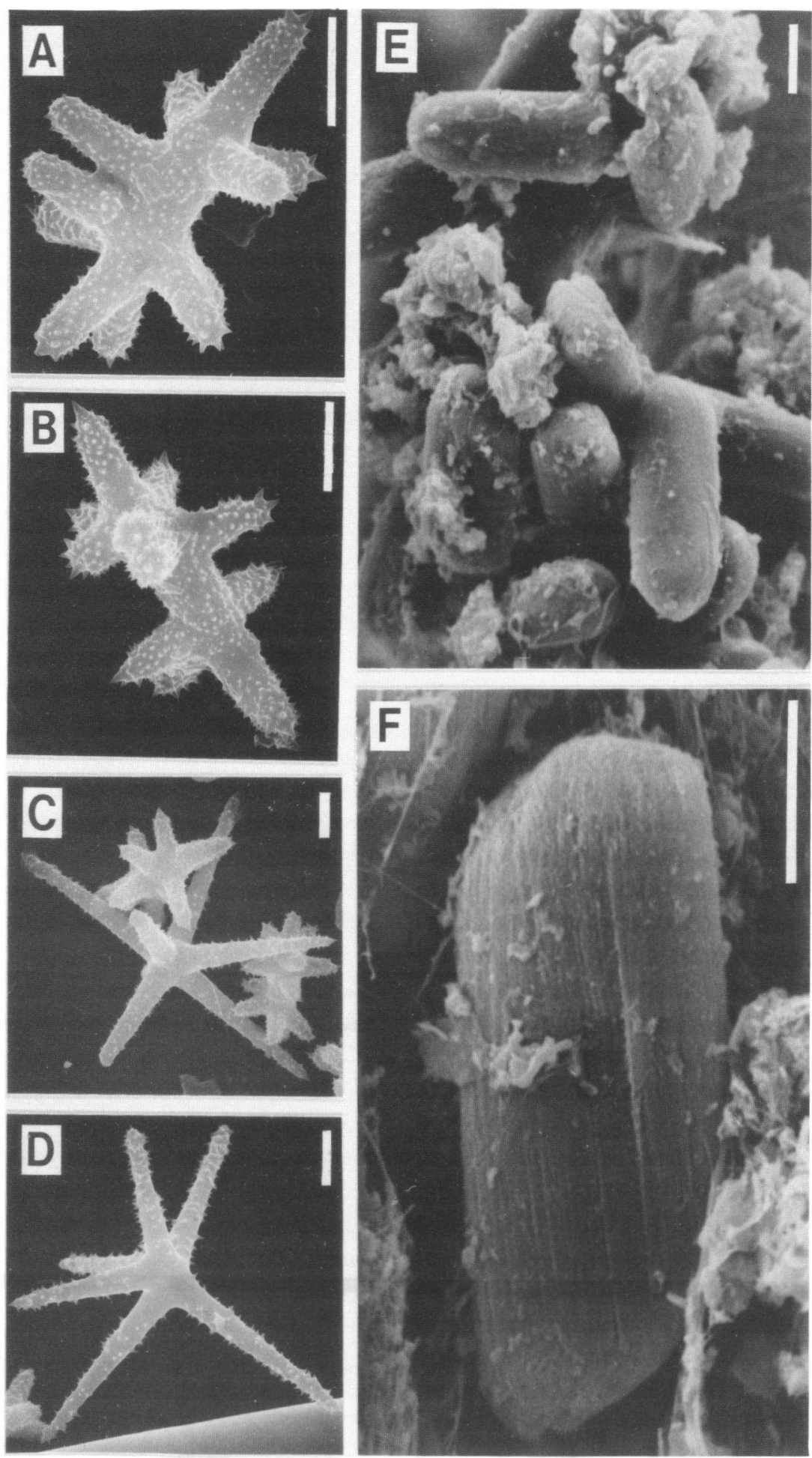

Plate I. Asteropus brasiliensis sp. n.: A, sanidaster; B, sanidaster; C, oxyaster and sanidasters; D, oxyaster; E, trichodragmata; F, trichodragma. Scales are all $5 \mu \mathrm{m}$ long. 
$4 \mathrm{~cm}$ high. They are firm, hardly compressible. Their colour alive is dark brown where exposed to the light, gradually becoming clearer towards the base of attachment of the sponge, which is frequently dirty-white. The choanosome is white. There is an easily discernible cortex, about $1 \mathrm{~mm}$ deep, characterized by large amounts of subspherical pigmented cells $(18 \times 25 \mu \mathrm{m})$. Both the holotype and Boury-Esnault's specimen show in spirit a brown choanosome and a whitish cortex.

The surface is minutely hispid, sometimes irregular, due to the presence of embedded sediment. Oscula, approximately $2 \mathrm{~mm}$ wide, are grouped on the apical darker part of the sponge. No firmly attached epibionts were seen at any of the specimens collected.

Skeleton: The cortical skeleton is characterized by an upper ectosomal crust of sanidasters, reinforced by huge amounts of small trichodragmata (up to more than 100 per $1000 \mu \mathrm{m}^{2}$ ). This layer is usually closely adhered to an intermediary one (approximately $200 \mu \mathrm{m}$ wide), consisting of tangentially arranged oxeas, sometimes difficult to distinguish from the underlying choanosomal skeleton. These oxeas are in the same size range as those in the choanosome, as demonstrated by the unimodal size-frequency distribution in the holotype ( $n=$ 150 ), and by the absence of any size distinction between dissociated spicules from the ectosome and the choanosome. The inner layer is composed mainly of radially disposed bundles of oxeas, having a lower spicular density than the choanosome, and being traversed by abundant aquiferous channels.

The choanosome consists of a dense skeleton of radially disposed oxeas. Large amounts of scattered oxeas may make parts of the skeleton very confused. Oxyasters are rare and seem to show no localization. Small trichodragmata are abundant, scattered throughout the sponge.

Spicules (see Fig. 1 a-d and Pl. I A-F; measurements in Table I; $s=$ standard deviation, $n=$ number of spicules measured):

Megascleres: Oxeas (Fig. 1 a) variable in size (unimodal distribution with mode at $700 \mu \mathrm{m}$ ), length 322-910.8-1984 $(s=325.8)$, width 6.3$26.8-60 \mu \mathrm{m}(s=2.1)(n=150)$; slender or robust, fusiform, tapering gradually, slightly curved at mid-length.

Microscleres: Sanidasters (Fig. 1 c; Pl. I A-B) spined all over. Spines usually larger at end of rays. Rays up to 15 , showing no tendency for a concentric arrangement. Irregular shape. Some rare reduced forms, sometimes smooth, may be present (perhaps developmental stages, never microrhabdlike); length $11.3-17.5 \mu \mathrm{m}(n=70)$. Oxyasters (Fig. $1 \mathrm{~b}$; Pl. I C-D) spined all over, sometimes with smooth centrum. Largest spines at distal third of rays. Rays (6-8), normally fusiform. Tapering, gradual or sudden; length 13.8-30.6-42.5 $\mu \mathrm{m}$ $(s=5.8)(n=43)$. Trichodragmata (Fig. $1 \mathrm{~d}$; Pl. I E-F) irregularly cylindrical (capsule-like), slightly flattened shape; length 12.6-22.7-28 $\mu \mathrm{m}(n=20)$.

Ecology. - Relatively common at the Cabo Frio region. The species is normally found under the zoanthid Palythoa sp. (which is not attached to the sponge), with only the darker apical part of the sponge apparent. The species has a considerable bathymetrical range ( 3 to $75 \mathrm{~m}$ depth).

Distribution. - Tropical southwest Atlantic.

Etymology. - The name refers to the distribution of the species, which is restricted to the Brazilian coast.

Remarks. - Of all western Atlantic Asteropus species, $A$. brasiliensis sp. n. seems closest to $A$. simplex (Carter, 1879) from the Indo West Pacific. A re-examination of a type slide from Carter's collection (BMNH, no registration number) revealed the unexpected occurrence of two categories of oxyasters $(20-32 \mu \mathrm{m}$ and $40-67 \mu \mathrm{m})$. In other respects it conforms precisely to spicular micrometries of $A$. brasiliensis $\mathrm{sp}$. $\mathrm{n}$. Trichodragmata are in the same size range $(17-25 \mu \mathrm{m})$, although less abundant in A. simplex.

Re-examination of Boury-Esnault's (1973) specimen, collected by the "Calypso" Expedition along the northeastern Brazilian coast and identified by her as $A$. simplex, revealed a slight tendency for bimodality in the size-frequency of the oxeas $(n=150)$. A similar pattern was noted in a paratype 
Table I. Individual spicule dimensions for specimens of Asteropus brasiliensis sp. $\mathrm{n}$. Means are in italics; other values are ranges; expressed as spicule length/width. The number of oxeas measured for both the holotype and Boury-Esnault's (1973) specimen was 150. In paratype UFRJ POR 2814, 100 oxeas were measured. For other measurements, $n=20$, except if otherwise stated. Values are in $\mu \mathrm{m}$.

\begin{tabular}{|c|c|c|c|c|}
\hline & oxeas & sanidasters & oxyasters & trichodragmata \\
\hline UFRJ POR 3022 & $422-1099-1984 / 12.5-35.3-60$ & $12.5-16.3$ & $22.5-29.4-38.8$ & $15.4-22.7-28$ \\
\hline \multicolumn{5}{|l|}{ Holotype } \\
\hline UFRJ POR 2814 & $322-781-1782 / 6.3-31.5-41.3$ & $12.5-17.5$ & $13.8-26.3(n=3)$ & $18.2-25.2$ \\
\hline \multicolumn{5}{|l|}{ Paratype } \\
\hline UFRJ POR 2889 & $570-990-1736 / 15-26-35$ & $11.3-15$ & not found & $16.8-23.8$ \\
\hline \multicolumn{5}{|l|}{ Paratype } \\
\hline UFRJ POR 2908 & $645-935-1314 / 10-34-45$ & $11.3-16.3$ & $30-33.5-38$ & $18.2-22.4$ \\
\hline \multicolumn{5}{|l|}{ Paratype } \\
\hline UFRJ POR 2913 & $570-1029-1786 / 11.3-24-45$ & $12.5-15$ & $25-30.4-35$ & $18.2-22.4$ \\
\hline \multicolumn{5}{|l|}{ Paratype } \\
\hline UFRJ POR 2915a & $446-950-1686 / 8.8-20.9-37.5$ & $12.5-13.8$ & $23.8-32.1-42.5$ & $12.6-16.8-21$ \\
\hline \multicolumn{5}{|l|}{ Paratype } \\
\hline UFRJ POR 3027 & $434-787-1215 / 10-15.9-20$ & $11.3-15$ & not found & $16.8-21$ \\
\hline \multicolumn{5}{|l|}{ Paratype } \\
\hline \multirow[t]{2}{*}{ Boury-Esnault (1973) } & $1245-1650 / 30-56$ & $15-20$ & $28-38$ & not given \\
\hline & $570-1026 / 9-20$ & & & \\
\hline (remeasured) & $405-923-1620 / 7.5-22.3-47.5$ & $12.5-16.3$ & $27.5-35.5-41.3$ & $14-17.6-19.6$ \\
\hline
\end{tabular}

of $A$. brasiliensis sp. n. (UFRJ POR 2814), although not as pronounced as in the previous specimen. As intermediate-sized oxeas are quite common in both specimens and no shape distinction can be found between smaller and larger oxeas, we considered this to be merely a case of intraspecific variation, and consequently BouryEsnault's specimen was assigned to $A$. brasiliensis sp. $\mathrm{n}$. It is considered distinct from $A$. simplex (sensu Carter) on the basis of possession of only one category of oxyasters.

The similarity between $A$. brasiliensis sp. n. and A. ketostea (De Laubenfels, 1950) (see below, Table II), as revealed by the tendency towards bimodality, is strongly contrasted by the smaller oxyasters and absence of trichodragmata in the latter species.

Asteropus syringiferus Van Soest \& Stentoft, 1988 (see below) is also close to the present species, differing in its peculiar habit (with fistules), slightly larger oxyasters and more slender sanidasters.

Asteropus brasiliensis sp. $\mathrm{n}$. is distinguished from other western Atlantic records of Asteropus by the possession of only one variable category of oxeas $(300-2000 \mu \mathrm{m})$, small and rare oxyasters $(14-43 \mu \mathrm{m})$ and relatively large and abundant trichodragmata (15-28 $\mu \mathrm{m})$ (Table II).

Asteropus ketostea (De Laubenfels, 1950)

Stellettinopsis ketostea De Laubenfels, 1950: 112-114; text-fig 50.

Material examined. - Two slides (thick-sections and spicules), from the type specimen from Bermuda (USNM, no reference number). De Laubenfels (1950) mentions a syntype in the BMNH collection (reg. no. 1948:8:6:47), but this could not be found by Miss S.M. Stone and is assumed to be lost.

Description (emended from De Laubenfels, 1950). - Shape encrusting to massive ( $1 \mathrm{~cm}$ thick), diameter of $2 \mathrm{~cm}$. Consistency firm, hard, slightly compressible. Surface minutely verrucose. Pores abundant over the entire surface, each about $60 \mu \mathrm{m}$ in diameter. Oscules not seen (perhaps some of the pores may be exhalant apertures). Colour black externally and grey in the interior. In alcohol it fades slightly.

Skeleton: The ectosomal skeleton is composed of large amounts of sanidasters interspersed with a skeleton of paratangential oxeas. A concentration of pigmented cells $(24 \times 11 \mu \mathrm{m})$, that may extend $160-320 \mu \mathrm{m}$ into the sponge, makes the ectosome 
Table II. Comparative data on spicule dimensions for all western Atlantic Asteropus species. Means are in italics; other values are ranges; expressed as spicule length/width. The number of oxeas measured was $150 \mathrm{in}$ A. brasiliensis sp. $\mathrm{n}$. and 100 in all the others. For other spicules, $n=20$. Values are in $\mu \mathrm{m}$.

\begin{tabular}{|c|c|c|c|c|c|}
\hline & oxeas 1 & oxeas 2 & sanidasters & oxyasters & trichodragmata \\
\hline Asteropus brasiliensis sp. $\mathrm{n}$. & $\begin{array}{l}322-911-1984 / \\
6.3-27-60\end{array}$ & absent & $11.3-17.5$ & $13.8-30.6-42.5$ & $12.6-22.7-28$ \\
\hline $\begin{array}{l}\text { Asteropus ketostea } \\
\text { (De Laubenfels, 1950) }\end{array}$ & $\begin{array}{l}216-426-551 / \\
1.5-3.5\end{array}$ & $\begin{array}{l}616-978-1404 / \\
6.4-25\end{array}$ & $11-14.7$ & $17-27$ & absent \\
\hline Asteropus niger sp. $\mathrm{n}$. & $\begin{array}{l}182-215-235 / \\
2.2-5.6\end{array}$ & $\begin{array}{l}1045-1966-2503 / \\
8-25-34\end{array}$ & $17-20$ & $42-57.6-98$ & $12.6-19.6$ \\
\hline $\begin{array}{l}\text { Asteropus syringiferus } \\
\text { Van Soest \& Stentoft, } 1988\end{array}$ & $\begin{array}{l}520-1010-1900 / \\
6.5-19.1-53\end{array}$ & absent & $11.2-19.6$ & $34-60$ & $18.2-25.2$ \\
\hline Asteropus vasiformis sp. $\mathrm{n}$. & $\begin{array}{l}632-1161-1650 / \\
19.6-39.2\end{array}$ & $\begin{array}{l}1750-2225-2805 / \\
51.8-86.8\end{array}$ & $7.5-22$ & $45-63-101$ & $18.2-23.8$ \\
\hline
\end{tabular}

much darker than the rest of the sponge in mounted sections. The pigmented cells are also found $1 \mathrm{~mm}$ deep in the sections, though here they are more sparse. Trichodragmata were not found.

The choanosomal skeleton has some loose ascending radial tracts of large oxeas. Many oxeas are scattered in confusion. The subectosomal region shows a reduced spicule content. The thinner oxeas appear to be restricted to the choanosome, where they are strewn at random; they are absent from both ectosomal and subectosomal regions. Oxyasters are restricted to the choanosome.

Spicules (see Table II for measurements):

Megascleres: Oxeas 1 slender, fusiform, tapering gradually; straight, slightly curved or sinuous; length 216-426-551 $(s=88)$, width $1.5-3.5 \mu \mathrm{m}$ $(n=40)$. Oxeas 2 fusiform, tapering gradually, slightly curved; length 616-978-1404 $(s=205)$, width 6.4-25 $\mu \mathrm{m}(n=80)$.

Microscleres: Sanidasters of variable shape; rays up to 15 , bifurcating or not, irregularly distributed over the shaft length; length 11-14.7 $\mu \mathrm{m}$. Oxyasters slender, rays $6-10$, completely microspined, with very small centrum; length 17-27 $\mu \mathrm{m}$.

Distribution. - Collected at $1 \mathrm{~m}$ depth, under a rock. Known only from Whalebone Bay, north shore of Bermuda, St. George's Parish.

Remarks. - The species can be distinguished from all other Atlantic Asteropus in having two categories of oxeas, very small oxyasters, and lacking trichodragmata.

Re-examination of the type preparations of $\boldsymbol{A}$. ketostea revealed the presence of two categories of oxeas (Table II), instead of only a single category as reported in the original description (De Laubenfels, 1950). Desqueyroux-Faúndez (1990) reported $A$. ketostea from Easter Island (Pacific), also with two categories of oxeas. Nevertheless, we consider this record to be highly dubious, because the sanidasters reported by her are almost three times as large (38 $\mu \mathrm{m})$ as in the type specimen $(11-15 \mu \mathrm{m})$; her specimen possibly represents a separate species.

The closest western Atlantic relative of $A$. ketostea seems to be $A$. brasiliensis sp. n., which differs by the possession of only a single category of oxeas, slightly larger oxyasters, and the abundance of trichodragmata.

Asteropus kaena (De Laubenfels, 1957), from Hawaii, studied on the basis of a holotype fragment (USNM 23540), is similar to A. ketostea in the absence of trichodragmata. The huge oxeas (2000-2400 $\mu \mathrm{m}$ long) reported by De Laubenfels in the original description were not found, thus strengthening its similarity to $A$. ketostea. Nevertheless, both species are considered to be valid on the basis that oxeas smaller than $800 \mu \mathrm{m}$ are rare in $A$. kaena, whereas oxeas only $400 \mu \mathrm{m}$ long are abundant in $A$. ketostea. A. kaena has also slightly smaller oxyasters $(16-20 \mu \mathrm{m})$. 

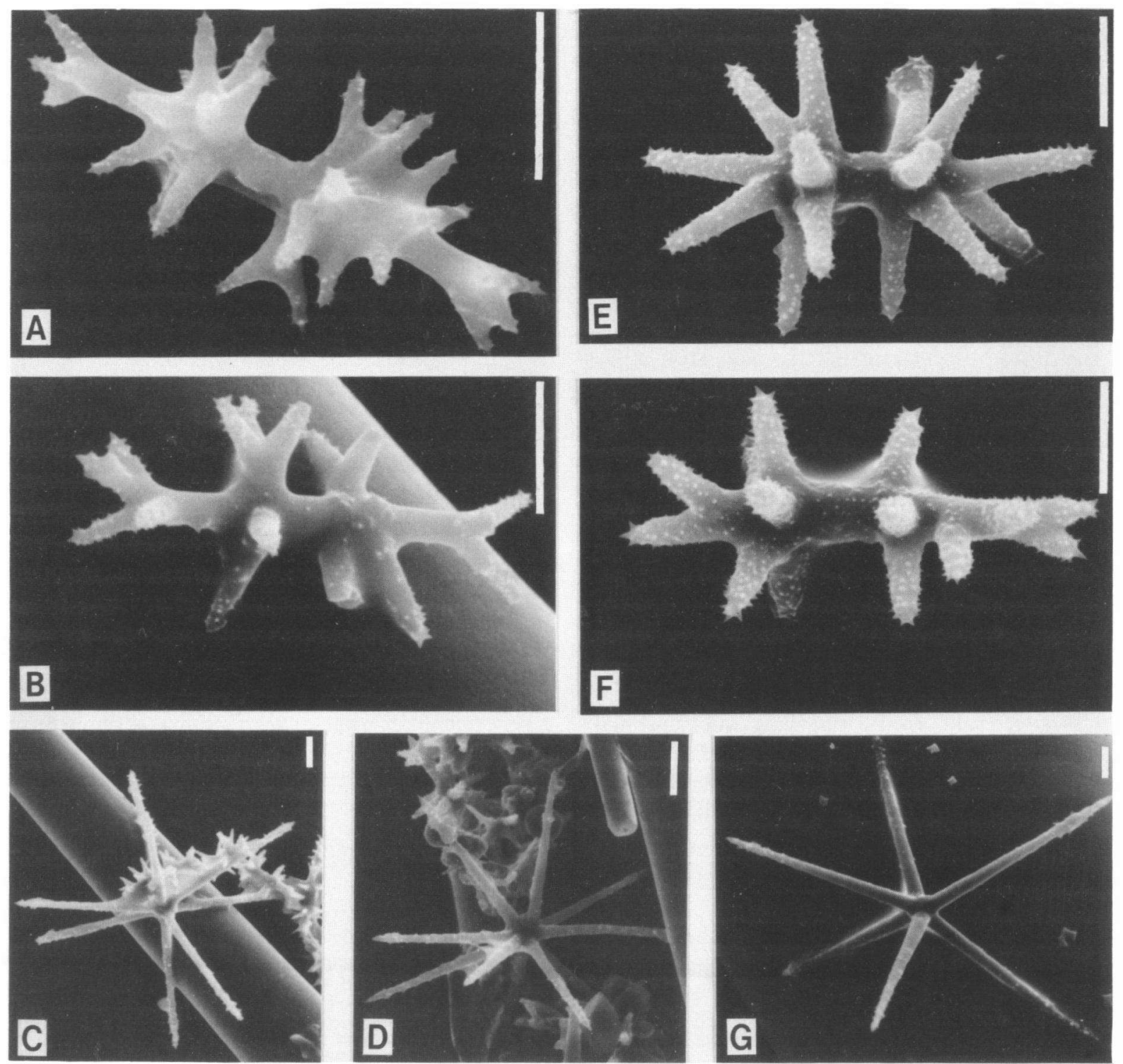

Plate II. A-D, Asteropus niger sp. n.: A, sanidaster; B, sanidaster; C, oxyaster; D, oxyaster. Scales are $5 \mu \mathrm{m}$ long. E-G, Asteropus vasiformis sp. n.: E, sanidaster; F, sanidaster; G, oxyaster. Scales are $5 \mu \mathrm{m}$ long.

\section{Asteropus niger sp. $\mathrm{n}$.}

(Fig. 2 a-e; Pl. II A-D)

Material examined. - Holotype: ZMA POR 5715, Blauwbaai, Curaçao $\left(68^{\circ} 59^{\prime} \mathrm{W} 12^{\circ} 08^{\prime} \mathrm{N}\right), 55 \mathrm{~m}$ depth, coll. W. Hoppe \& $\mathrm{M}$. Reichert, 20/X/1984.

Description. - One fragment, $2 \mathrm{~cm}$ long, $1.2 \mathrm{~cm}$ wide, $2 \mathrm{~cm}$ high. Consistency tough, incompressible. Colour alive black. In ethanol the specimen is deep brown, almost black. The surface is hispid and completely overgrown by haplosclerid sponges. No oscules are apparent.

Skeleton: The ectosomal skeleton is characterized by large numbers of scattered oxeas, some of them tangential to the surface. This arrangement of the spicules can extend more than $5 \mathrm{~mm}$ deep into the sponge. The oxeas may protrude beyond the surface making it hispid. Masses of pigmented cells $(14 \times 11 \mu \mathrm{m})$ are visible near the surface, becoming 

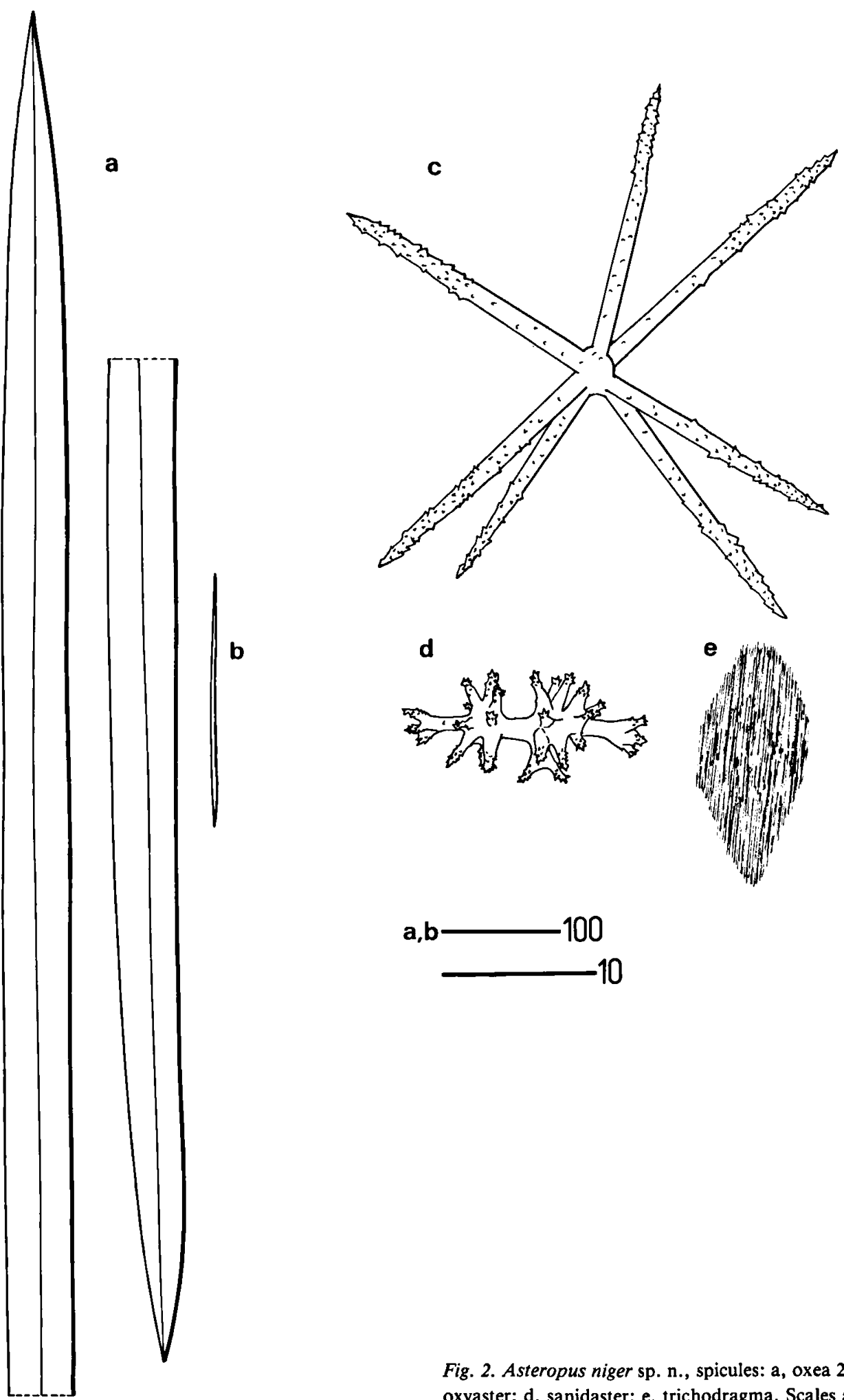

Fig. 2. Asteropus niger sp. n., spicules: a, oxea 2; b, oxea 1; c, oxyaster; d, sanidaster; e, trichodragma. Scales are in $\mu \mathrm{m}$. 
less abundant below $1 \mathrm{~mm}$ deep. Some of the protruding spicules core spongin fibres of an epibiont, Callyspongia strongylata Hartman, 1955.

The choanosome has a more or less radially oriented skeleton of oxeas, with some very loose tracts. Spicule density is high. Colour is darker in the choanosome (deep reddish brown after mounting) than in the ectosome (dirty yellow to light brown). Oxyasters and trichodragmata are scarce and seem to be restricted to the choanosome. Sanidasters are concentrated near the surface, though less abundant than in other species.

Spicules (see Fig. 2 a-e and Pl. II A-D; measurements in Table II):

Megascleres: Oxeas 1 (Fig. 2 b) slender, almost raphidiform, slightly curved; length 182-215-235, width 2.2-5.6 $\mu \mathrm{m}(n=20)$. Oxeas 2 (Fig. 2 a) slender and slightly curved, fusiform, tapering gradually; length 1045-1966-2503 $(s=314.9)$, width 8-25-34 $\mu \mathrm{m}(n=100)$.

Microscleres: sanidasters (Fig. 2 d; Pl. II A-B), spines concentrated on rays, largest spines at end of rays, up to 30 rays in one spicule; length $17-20 \mu \mathrm{m}$ $(n=20)$. Oxyasters (Fig. 2 c; Pl. II C-D) extremely slender, rare, spined all over, but spines becoming larger and more abundant closer to end of rays; rays 6-10; length 42-57.6-98 $\mu \mathrm{m} \quad(n=20)$. Trichodragmata (Fig. 2 e) of variable shape, somewhat capsule-like; length $12.6-19.6 \mu \mathrm{m}(n=20)$.

Distribution. - Collected on the reef slope at $55 \mathrm{~m}$ depth, at Blauwbaai, Curaçao.

Etymology. - The name refers to the black live colour reported for the specimen, but more especially to the dark, almost black choanosome, a feature not usual in Asteropus.

Remarks. - Asteropus niger sp. n. is distinguished from other Atlantic species of Asteropus by the possession of two distinct categories of oxeas, one very small $(180-230 \mu \mathrm{m})$ and one very large (1000-2500 $\mu \mathrm{m})$. Its sanidasters are more abundantly rayed than in other Asteropus species.

Asteropus vasiformis sp. n. (see below; Table II) is closest to $A$. niger sp. $\mathrm{n}$. on account of its two categories of oxeas - the larger one attaining a huge size - large oxyasters, and deep-water habitat. Both species are considered to be distinct on the basis of the much smaller size of the smaller category of oxeas in the latter, its densely rayed sanidasters, and its massive shape (as opposed to cup shape in $A$. vasiformis sp. n.).

Asteropus syringiferus Van Soest \& Stentoft, 1988

Asteropus syringiferus Van Soest \& Stentoft, 1988: 32-34; textfig. 14, Pl. V figs. 1-2.

Material examined. - Holotype: ZMA POR 5307, off Holetown, Barbados, $100 \mathrm{~m}$. Paratype: ZMA POR 5308, off Holetown, Barbados, $100 \mathrm{~m}$.

Description (emended from Van Soest \& Stentoft, 1988). - The holotype is a round mass, $2.5 \mathrm{~cm}$ in diameter, incrusted with dead shells, bearing two conspicuous hollow fistules; the larger fistule, $2 \mathrm{~cm}$ in length, $4 \mathrm{~mm}$ in diameter, is closed at the apex; the shorter one bears an apical oscule. The paratype is a smaller sphere, $1 \mathrm{~cm}$ in diameter. Both specimens have a rough surface; the consistency is hard, almost incompressible. The colour in spirit is grey in the main body and dirty-white at the fistules.

Skeleton: The ectosomal skeleton is composed of paratangentially oriented oxeas carrying numerous sanidasters. The choanosomal skeleton is (para-) tangential to the surface in the fistule walls, and confusedly radiate in the main body. Trichodragmata (not mentioned by Van Soest \& Stentoft, 1988) are abundant throughout the sponge.

Spicules (see Table II for measurements):

Megascleres: Oxeas fusiform, tapering gradually, slightly bent; length 520-1010-1900 $(s=244)$, width 6.5-19.1-53 $\mu \mathrm{m}(n=100)$.

Microscleres: Sanidasters of variable shape, shaft mostly thin; rays up to 15 , bifurcating or not, irregularly distributed over the shaft length; small spines concentrated on the rays; length 11.2-19.6 $\mu \mathrm{m}(n=20)$. Oxyasters slender, with a very small centrum; spines concentrated on distal half of rays; rays $8-12$; length $34-60 \mu \mathrm{m}(n=20)$. Trichodragmata variable in shape, slightly capsule-like; length $18.2-25.2 \mu \mathrm{m}(n=20)$. 
Distribution. - Rare, on shelly substrate at $100 \mathrm{~m}$ depth, off Barbados.

Remarks. - The spicule sizes of this species are close to those of $A$. brasiliensis sp. n. However, the remarkably different habit and habitat, the irregular shape of the trichodragmata, and the spines confined to the distal half of the rays of the oxyasters are here considered strong evidence for differentiating these species.

Asteropus vasiformis sp. $\mathrm{n}$.

(Fig. 3 a-e; Pl. II E-G)

Asteropus simplex sensu Van Soest \& Stentoft, 1988: 31-32, text-fig. 13, Pl. IV-fig. 6 (non Stellettinopsis simplex Carter, 1879).

Material examined. - Holotype: ZMA POR 5302, off Payne's Bay, Barbados $\left(13^{\circ} 10^{\prime} \mathrm{N} 59^{\circ} 40^{\prime} \mathrm{W}\right), 153 \mathrm{~m}$ depth; coll. N. Stentoft, $1978 / 80$.

Description (emended from Van Soest \& Stentoft, 1988). - Cup-shaped, with one side not quite closed; $10 \mathrm{~cm}$ high, $7 \mathrm{~cm}$ in diameter at the top, with steep walls. Six oscules, one facing four others on opposing inner sides of the break in the cup wall, one outside the cup wall. Rim and inner surface smooth, outer side hispid. Consistency tough, incompressible, crumbly. Colour in the dry state is light brown at the rim and inner side, and dark purple at the outer side but this is probably not the proper live colouration.

Skeleton: The ectosomal skeleton is made up of a loose layer of tangential oxeas carrying abundant sanidasters and some trichodragmata. These oxeas are smaller than the choanosomal ones, as demonstrated by a bimodal size frequency distribution. The choanosomal skeleton has a radial architecture of huge oxeas which often protrude beyond the surface. Oxyasters become abruptly abundant $3 \mathrm{~mm}$ beneath the surface.

Spicules (see Fig. 3 a-e and Pl. II E-G; measurements in Table II):

Megascleres: Oxeas 1 (Fig. 3 b) fusiform, slender or robust, tapering gradually; slightly curved; length $632-1161-1650(s=258)$, width $19.6-39.2$ $\mu \mathrm{m}(n=45)$. Oxeas 2 (Fig. 3 a) fusiform, slender or robust, tapering gradually; slightly curved; length $1750-2225-2805(s=229)$, width 51.8-86.8 $\mu \mathrm{m}$ $(n=55)$.

Microscleres: sanidasters (Fig. 3 d; Pl. II E-F) spined all over; largest spines at end of rays; rays up to 14 ; length $7.5-22 \mu \mathrm{m}(n=20)$. Oxyasters (Fig. 3 c; Pl. II G) large; extremely slender and abundant; spined all over, largest spines at end of rays; rays $6-10$; length $45-63-101 \mu \mathrm{m}(n=20)$. Trichodragmata (Fig. 3 e) irregularly cylindrical (capsule-like), slightly flattened shape; length 18.2-23.8 $\mu \mathrm{m}$ $(n=20)$.

Distribution. - Apparently quite rare at $153 \mathrm{~m}$ depth, off Barbados.

Etymology. - The name refers to the cup shape.

Remarks. - Important differences between $A$. vasiformis sp. n. and $A$. simplex (examined from a type slide) are the occurrence of two oxyaster categories (20-32 and 40-67 $\mu \mathrm{m})$ and only one category of oxeas (780-1500 $\mu \mathrm{m}$ long) in the latter.

Asteropus vasiformis sp. n. can be distinguished from other Atlantic species of Asteropus by its two categories of oxeas, both with means above 1000 $\mu \mathrm{m}$, large oxyasters (up to $100 \mu \mathrm{m}$ ), abundance of microscleres, its cup shape, and deep-water habitat. Its closest relative seems to be $A$. niger sp. n., which differs in having a much smaller category of small oxeas, massive habit, and less abundantly rayed sanidasters.

\section{Key to the western Atlantic Asteropus}

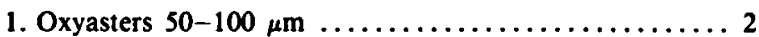

- Oxyasters $<50 \mu \mathrm{m} \ldots \ldots \ldots \ldots \ldots \ldots \ldots \ldots \ldots$

2. Two distinct categories of oxeas (one $<500 \mu \mathrm{m}$ long), sanidasters with up to 30 rays, shape massive. $A$. niger sp. $n$.

- Two categories of oxeas with mean lengths both above 1000 $\mu \mathrm{m}$, sanidasters with at most 15 rays, cup-shaped ....... .......................... vasiformis $\mathrm{sp.} \mathrm{n}$.

3. Trichodragmata abundant $\ldots \ldots \ldots \ldots \ldots \ldots \ldots \ldots 4$

- No trichodragmata .... A. ketostea (De Laubenfels, 1950)

4. Shape massive-sprawling, oxyasters $14-43 \mu \mathrm{m} \ldots \ldots \ldots \ldots$ $\ldots \ldots \ldots \ldots \ldots \ldots \ldots \ldots \ldots$. brasiliensis sp. $\mathrm{n}$.

- Shape globular, with fistules, oxyasters 34-60 $\mu \mathrm{m} . . . \ldots$. .......... A. syringiferus Van Soest \& Stentoft, 1988 



C

d

e
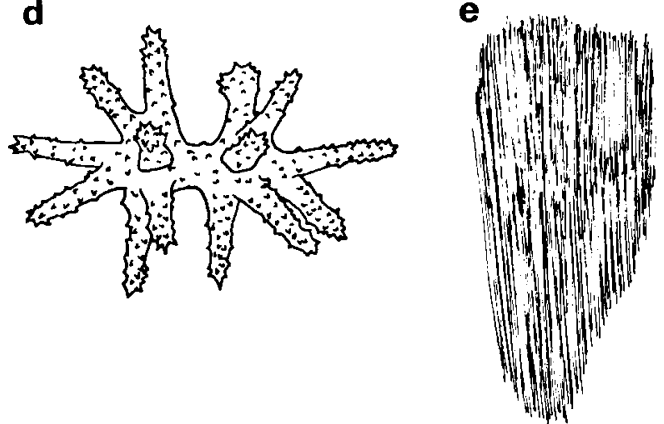

$a, b-100$

$-10$

Fig. 3. Asteropus vasiformis sp. n., spicules: a, oxea 2; b, oxea $1 ; \mathrm{c}$, oxyaster; d, sanidaster; e, trichodragma. Scales are in $\mu \mathrm{m}$. 


\section{Discussion}

\section{Indo-Pacific records of Asteropus}

A study of Carter's type slide of $A$. simplex (BMNH, no reference number) revealed the occurrence of two categories of oxyasters, which renders the specimen unique among other records of the species. No Atlantic Asteropus is known to have two categories of oxyasters, which is here considered as strong evidence to restrict the use of the name $A$. simplex to Indo-Pacific records.

Data from the literature on Asteropus are barely informative as most authors give only representative measurements, without ranges and/or means. The larger oxeas presently found in both the type specimen and in Hong Kong specimens (the latter reported by Van Soest, 1981) were in the $1400-1600 \mu \mathrm{m}$ range, which is much smaller than Dendy's (1924) $2100 \mu \mathrm{m}$, Wilson's (1925) $3100 \mu \mathrm{m}$ and Bergquist's (1968) $2900 \mu \mathrm{m}$.

The live colour of $A$. simplex has been reported in the literature only by Bergquist (1968: light yellow; 1969: white), and by Desqueyroux-Faúndez (1990: greyish to black). The latter record of $A$. simplex is considered highly dubious on account of the possession of much smaller oxyasters $(13 \mu \mathrm{m}$; in the same size range as in $A$. kaena from the Hawaii Islands) and a second, also much smaller category of oxeas $(130 \mu \mathrm{m})$. Many specimens were reported as being dark-coloured in spirit (e.g. Dendy, 1916a; Lévi, 1967) but it is not possible to ascertain whether or not this is the live colour of the specimen.

Remarkably, all the Asteropus species studied, except for $A$. ketostea and $A$. kaena, possess more or less abundant trichodragmata. These structures have not previously been reported in the genus, and this discovery has a bearing on systematics, as will be established below. This recent discovery of trichodragmata widespread in Asteropus specimens, as well as a second category of oxyasters in the type specimen of $A$. simplex, shows how easily spicule categories have probably been overlooked in previous descriptions of Asteropus. It is clear that a thorough revision of Carter's $(1879,1886)$, Dendy's (1905, 1916a, 1916b, 1924), Hentschel's
(1909), Dendy \& Frederick's (1924), Wilson's (1925), Lévi's (1967), Bergquist's (1968, 1969), Tanita's (1970), Vacelet et al.'s (1976), Desqueyroux-Faúndez's (1990), and Tanita \& Hoshino's (1990) specimens is needed in order to ascertain what the real variability in $A$. simplex is. It is predicted that this will reveal the occurrence of several discrete Indo-Pacific species.

\section{Phylogenetic affinities of Asteropus}

Bergquist (1965) observed that two groups of species could be recognized within Asteropus. The first one had true sanidasters and included $A$. simplex, $A$. ketostea, and $A$. kaena (the "simplex" group). To this assemblage we can add $A$. syringiferus, $A$. brasiliensis sp. n., $A$. niger sp. n., and $A$. vasiformis sp. $\mathrm{n}$. The second group was characterized by having spiny microrhabds and included $A$. sarasinorum (Thiele, 1899) and $A$. cherbonnieri (Lévi, 1961) (the "sarasinorum" group). Reexamination of Lévi's (1965) Stellettinopsis solida, also associated with the latter group, revealed that triaenes were relatively common and a proper tangential ectosomal skeleton was absent, so that the species is here assigned to Ecionemia Bowerbank, 1862.

Bergquist (1965) considered that the difference between the two above-mentioned Asteropus species groups was similar to that found between $A n$ corina (with sanidasters) and Ecionemia (with spiny microrhabds). This had also previously been pointed out by Sollas (1888) and Topsent (1928). As both genus groups were considered synonyms by most authors, Bergquist (1965) decided to keep the Asteropus lineages under the same generic assemblage.

The present discovery of abundant small trichodragmata in many species of Asteropus assigned to the "simplex" group, but not in $A$. sarasinorum (e.g. ZMA POR 8049, from Indonesia, identified by the second author) is here considered strong evidence for generic distinction between both lineages. Lévi (1961) did not mention trichodragmata for $A$. cherbonnieri either. The name Melophlus Thiele (1899) is available for the 
"sarasinorum" group, and is presently considered valid. $A$. sarasinorum is considered distinct from true Ancorina/Ecionemia on the basis of its possession of a very thick tangential skeleton of oxeas, and can be defined as follows:

\section{Melophlus Thiele, 1899}

Type species: Melophlus sarasinorum Thiele, 1899, by monotypy.

Diagnosis. - Ancorinidae without triaenes, with a thick tangential ectosomal skeleton of megascleres, and a microsclere complement of oxyasters and spiny microrhabds.

Species included: $M$. sarasinorum Thiele, 1899 (type species) and $M$. cherbonnieri (Lévi, 1961).

\section{Family allocation of Asteropus}

Various authors (Sollas, 1888; Topsent, 1900; Bergquist, 1968) have pointed out that generic differences within the Coppatiidae paralleled those of certain genera of Ancorinidae, but this apparently did not motivate these authors to abandon the first family. Still, if characters such as the possession of euasters, and/or microrhabds, and/or trichodragmata are considered primitive (and there can be little doubt of this in view of the wide distribution of these characters over the tetractinomorphs), there are only two coppatiid synapomorphies of dubious value remaining, viz. the absence of triaenes and the occurrence (in most coppatiids) of a complement of tangential megascleres.

The first synapomorphy, the absence of triaenes, is a suspect character, since "lipotriaene" Stelletta and Geodia species have been reported frequently, e.g. S. distincta (Thiele, 1900, as Rhabdastrella), $S$. sterrastrea (Row, 1911, as Diastra), and $S$. cribriporosa (Dendy, 1916a, as Aurora); quite a few are disguised as "Jaspis" or "Dorypleres" Sollas, 1888. Relationships of Stelletta Schmidt, 1862, Rhabdastrella Thiele, 1900, and Diastra Row, 1911, still need to be re-examined. In fact there is little ground for the assumption that loss of triaenes did not happen frequently and independently in various ancorinid groups.
The second synapomorphy could be genuine if the various tangential conditions were homologous. However, the condition in Jaspis s.s. - i.e. conforming to that of the type species, J. johnstoni (Schmidt, 1862) - seems to be widely different from that found in Asteropus-Melophlus-Holoxea s.s.: Jaspis s.s. has small oxeas forming a tightly arranged fine-grained surface, leaving characteristic round pore fields free of spicules, while the other taxa have an almost paratangential, confused arrangement of oxeas of intermediate or large size. Holoxea violacea Boury-Esnault, 1973 has no tangential skeleton, but this is interpreted as a subsequent loss.

On the other hand, Asteropus microscleres are closely similar to those of Stryphnus Gray, 1867, as already suggested by Sollas (1888) and Van Soest \& Stentoft (1988), and the somewhat irregular, confused/radial arrangement of choanosomal megascleres is also comparable. It is not difficult to consider both genera as closely related, differing in the absence of triaenes and possession of trichodragmata in Asteropus. Holoxea Topsent, 1892, may be associated with this group on account of its trichodragmata. Assigned species are $H$. furtiva Topsent, 1892 (specimen studied: ZMA POR 9760, Cape Verde, identified by the second author), $\boldsymbol{H}$. collectrix Thiele, 1903 (specimen studied: ZMA POR 3053, Siboga Expedition, det. M. Burton; the type specimen could not be found in the Senckenberg Museum, Frankfurt), and $H$. violacea BouryEsnault, 1973 (specimen studied: fragment from the type specimen, Brazilian coast). The genus is considered valid on the basis of the loss of oxyasters. Melophlus shows important similarities with Ecionemia: the acanthomicrorhabds of both are similar in shape (centrotylote) and size.

Bergquist (1968) erected the genus Lamellomorpha for L. strongylata, a species having sanidasters in combination with a loose skeleton of flexuous strongyles. The affinities of this species remain obscure. She also assigned Coppatias baculifer Kirkpatrick, 1903, to Lamellomorpha, but it lacks the "streptaster" category present in the type species, L. strongylata Bergquist, 1968. Its megascleres are also true oxeas, which makes it closer to true Ancorina/Ecionemia, and especially to Hezekia De 
Laubenfels, 1934, which was erected for an Ancorina-like species $(H$. demera) lacking euasters.

Jaspis is similarly problematic, where many alleged Jaspis do not conform to J. johnstoni but are like Stelletta, although they lack triaenes. For the latter group the name Dorypleres Sollas, 1888 is available; if the loss of triaenes is considered to be a synapomorphy of a related group of Stelletta-like species, then re-erecting Dorypleres could be considered. The phylogenetic relationships of Jaspis s.s. remain obscure. If the ectosomal small oxeas are homologous to the microxeas of Penares Gray, 1867 (Burton \& Rao, 1932; Bergquist, 1968), these two could be related. However, certain Jaspis such as J. serpentina Wilson, 1925 share similarities in their microscleres with Hemiasterella.

The genus Jaspis is badly in need of a revision. Previous efforts to split the genus (i.e. Lindgren, 1898; Thiele, 1900, 1903; Topsent, 1904) were all considered impractical by Dendy (1916a), who was followed by Wilson (1925). The question that arises is whether or not all Jaspis form a monophyletic assemblage. Its type species, J. johnstoni (Schmidt, 1862) - hypothesized to be of pachastrellid origin by Dendy (1916a) and Bergquist (1968) - has much smaller oxeas than those normally found in Astrophorida and the remaining coppatiids. BouryEsnault (1973) mentioned that two species groups were recognizable within Jaspis: the first, with microxeas (e.g. J. johnstoni and J. salvadori Boury-Esnault, 1973) and the second, without microxeas (e.g. J. reptans [Dendy, 1905], J. topsenti Thiele, 1900 and $J$. novaezelandiae Dendy, 1924). Boury-Esnault (1973) mistakenly assigned $J$. coriacea (Carter, 1886) to the second group. Carter (1886) clearly mentions the presence of a small category of oxeas (100 $\mu \mathrm{m}$ long), restricted to the surface of his specimen. Jaspis reptans was described without a tangential skeleton of oxeas, which makes it like Burton \& Rao's (1932) "lipotriaenose Stelletta" (or "reduced stellettids" [ = ancorinids] sensu Bergquist, 1968). The relationships between reduced ancorinids and "coppatiids" seem particularly close when certain genera (characterized by a slightly reduced radiality) are considered. In this way, Penares Gray, 1867 is comparable to Jaspis (at least those with small ectosomal oxeas);
Stryphnus Sollas, 1888 and Ancorina are comparable to Asteropus (sanidasters), and Ecionemia is comparable to Melophlus and Holoxea (spiny microrhabds).

Based on the above rationale, which follows the collective ideas of Row (1911), Dendy (1916a), De Laubenfels (1936), Bergquist (1968 and pers. comm.), and Van Soest \& Stentoft (1988), the polyphyletic origin of the Coppatiidae cannot be denied. We postulate that the loss of triaenes occurred in several ancorinid lineages and that the presence of a complementary, variously developed, tangential ectosomal skeleton cannot be used as a synapomorphic character for a group bearing such a diverse asterose microsclere complement. The occurrence of a tangential ectosomal skeleton in Jaspis, Asteropus, Holoxea, Melophlus, Neamphius, and Lamellomorpha is here interpreted as an adaptive answer, as a way of strengthening a skeleton that has lost the "umbrella" formed by the cladomes of the ectosomal triaenes.

These conclusions show that the family Coppatiidae, as presently understood, is polyphyletic. The genera Asteropus, Melophlus, and Holoxea are transferred to the Ancorinidae. The family Coppatiidae is provisionally retained to accommodate Jaspis, Neamphius, and Lamellomorpha until a more complete revision of Ancorinidae, Pachastrellidae, Coppatiidae, and related "lithistid" forms has been undertaken. The affinities of the restricted Coppatiidae must remain undecided until then.

\section{Acknowledgements}

The authors wish to thank Dr. N. Boury-Esnault (Marseille), Dr. Klaus Rützler (Washington), and Miss S.M. Stone (London) for sending specimens on loan. Mrs. Chantal Bezac (Marseille) is thanked for technical assistance in obtaining the SEM photos A-D of Plate I. Fieldwork in Arraial do Cabo (Brazil) was supported by grants from Conselho de Ensino para Graduados from the Universidade Federal do Rio de Janeiro (CEPG-UFRJ) and from Fundação de Amparo à Pesquisa do Estado do Rio de Janeiro (FAPERJ). The first author received a fellowship from Conselho Nacional de Desenvolvimento Cientifico e Tecnológico from Brazil (CNPq) to undertake Ph.D. studies at the University of Amsterdam. A first draft of this paper was greatly improved after valuable comments from two anonymous referees. 


\section{References}

Berg, C., 1899. Substitución de nombres genéricos, III. Comun. Mus. nac. Buenos Aires, 1: 77-80.

Bergquist, P.R., 1965. The sponges of Micronesia, part 1. The Palau Archipelago. Pacif. Sci., 19: 123-204.

Bergquist, P.R., 1968. The marine fauna of New Zealand: Porifera, Demospongiae, part 1 (Tetractinomorpha and Lithistida). Bull. N. Z. Dep. scient. ind. Res., 188 (= Mem. N. Z. oceanogr. Inst., 37): 1-105.

Bergquist, P.R., 1969. Shallow water Demospongiae from Heron Island. Univ. Qd. Pap. Gt. Barrier Reef Comm., 1 (4): 63-72, pls. 1-2.

Bergquist, P.R. \& W.D. Hartman, 1969. Free amino acid patterns and the classification of the Demospongiae. Mar. Biol., 3 (3): 247-268.

Boury-Esnault, N., 1973. Campagne de la Calypso au large des côtes atlantiques de l'Amérique du Sud (1961-1962). I, 29. Spongiaires. Annls. Inst. océanogr., 49 (Suppl.) (= Résult. scient. Camp. Calypso, 10): 263-295. $\Rightarrow$

Bowerbank, J.S., 1862. On the anatomy and physiology of the Spongiadae, part III. Phil. Trans. roy. Soc. London, 152: 1087-1135, pls. LXXII-LXXIV.

Buizer, D.A.G. \& R.W.M. van Soest, 1977. Mycale micracanthoxea nov. spec. (Porifera, Poecilosclerida) from The Netherlands. Neth. J. Sea Res., 11 (3/4): 297-304, pls. I-II.

Burton, M. \& H.S. Rao, 1932. Report on the shallow-water marine sponges in the collections of the Indian Museum, part I. Rec. Indian Mus., 34: 299-356, pl. XVIII.

Carter, H.J., 1879. Contributions to our knowledge of the Spongida. Ann. Mag. nat. Hist., (5) 3 (33): 284-304, pls. XXV-XXVII; (38): 343-360, pls. XXVIII-XXIX.

Carter, H.J., 1886. Descriptions of sponges from the neighbourhood of Port Philip Heads, South Australia, continued. Ann. Mag. nat. Hist., (5) 17 (5): 40-53; (12): 112-127; (40): 431-441; (47): 502-516; and (5) 18 (6): 34-55; (15): 126-149.

Dendy, A. 1905. Report on the sponges collected by Prof. Herdman at Ceylon in 1902. Report to the Government of Ceylon on the pearl oyster fisheries of the Gulf of Manaar, 3 (Suppl. 18): 57-246, pls. I-XVI (Royal Society, London).

Dendy, A., 1916a. Report on the Homosclerophora and Astrotetraxonida collected by H.M.S. "Sealark" in the Indian Ocean. In: Reports of the Percy Sladen Trust Expedition to the Indian Ocean in 1905, Vol. 6. Trans. Linn. Soc. Lond., (2, Zool.) 17: 225-271, pls. 44-48.

Dendy, A., 1916b. Report on the non-calcareous sponges collected by Mr. James Hornell at Okhamandal in Kattiawar in 1905-06. In: J. Hornell, Report to the Government of Baroda on the marine zoology of Okhamandal in Kattiawar, 2 (3): 93-146, pls. 1-4 (Williams \& Norgate, London).

Dendy, A., 1924. Porifera. Part 1. Non-Antarctic sponges. Nat. Hist. Rep. Br. antarct. Terra Nova Exped., 6 (3): 269-392, pls. I-XV.

Dendy, A. \& L.M. Frederick, 1924. On a collection of sponges from Abrolhos Islands, Western Australia. J. Linn. Soc. (Zool.), 35: 477-519, pls. 25-26.
Desqueyroux-Faúndez, R., 1990. Spongiaires (Demospongiae) ' de l'Ile de Pâques (Isla de Pascua). Revue suisse Zool., 97 (2): 373-409.

Gray, J.E., 1867. Notes on the arrangement of sponges, with the description of some new genera. Proc. zool. Soc. Lond., 1867: 492-558, pls. XXVII-XXVIII.

Hallmann, E.F., 1912. Report on the sponges obtained by the F.I.S. "Endeavour" on the coasts of New South Wales, Victoria, South Australia, Queensland and Tasmania, 1909-10, part 1. Zool. Results Fish. Experiments Endeavour, 2: 117-300, pls. 21-36.

Hartman, W.D., 1955. A collection of sponges from the west coast of the Yucatan Peninsula with descriptions of two new species. Bull. mar. Sci. Gulf Caribb., 5 (3): 161-189.

Hechtel, G.J., 1976. Zoogeography of Brazilian marine Demospongiae. In: F.W. Harrison \& R.R. Cowden (eds.), Aspects of sponge biology. Symposium, Albany, N.Y., U.S.A., May 1975: 237-260 (Academic Press, New York).

Hentschel, E., 1909. Tetraxonida, 1. Teil. In: W. Michaelsen \& R. Hartmeyer (eds.), Die Fauna Südwest-Australiens, 2 (21): 347-402, pls. XXII-XXIII (G. Fischer, Jena).

Hentschel, E., 1923. Erste Unterabteilung der Metazoa: Parazoa, Porifera $=$ Schwämme. In: W. Kükenthal \& $T$. Krumbach (eds.), Handbuch der Zoologie, 1. Protozoa, Porifera, Coelenterata, Mesozoa: 307-418 (W. de Gruyter, Berlin \& Leipzig).

Hooper, J.N.A., 1986. Revision of the marine sponge genus Axos Gray (Demospongiae: Axinellida) from North-West Australia. The Beagle, Occ. Pap. Northern Territory Mus. Arts Sci., 3 (1): 167-189.

ICZN, 1985. International Code of Zoological Nomenclature adopted by the XX General Assembly of the International Union of Biological Sciences (3rd ed.): i-xx, 1-338 (International Trust for Zoological Nomenclature in association with British Museum (Natural History), London; University of California Press, Berkeley \& Los Angeles).

Kirkpatrick, R., 1903. Descriptions of South African sponges, part III. Mar. Invest. S. Afr., 2: 233-264, pls. V-VI.

Lamarck, [J.B.P.A. de Monet] de, 1813-14. Sur les Polypiers empâtés. Annls. Mus. Hist. nat. Paris, 20: 294-312 (published 1813); 370-386, 432-458 (published 1814).

Laubenfels, M.W. de, 1934. New sponges from the Puerto Rican deep. Smithson. misc. Collns., 91 (17): 1-28.

Laubenfels, M.W. de, 1936. A discussion of the sponge fauna of the Dry Tortugas in particular and the West Indies in general, with material for a revision of the families and orders of the Porifera. Publs. Carnegie Inst. Wash., 467 (= Pap. Tortugas Lab., 30): i-iii, 1-225, pls. 1-22, 1 map.

Laubenfels, M.W. de, 1950. The Porifera of the Bermuda archipelago. Trans. zool. Soc. London, 27: 1-154, pls. I-II.

Laubenfels, M.W. de, 1953. Sponges from the Gulf of Mexico. Bull. mar. Sci. Gulf Caribb., 2: 511-557.

Laubenfels, M.W. de, 1957. New species and records of Hawaiian sponges. Pacif. Sci., 11 (2): 236-251.

Lévi, C., 1961. Les Spongiaires de l'lle Aldabra. Annls. Inst. océanogr. Monaco, (N.S.) 39 (= Résult. scient. Camp. Calypso, 14): 1-32, pls. 1-2. 
Lévi, C., 1965. Spongiaires récoltés par l'expédition israélienne dans le sud de la Mer Rouge en 1962. Israel S. Red Sea Exped. Rep., 13 (= Bull. Sea Fish. Res. Stn. Israel, 40): 3-27.

Lévi, C., 1967. Démosponges récoltées en Nouvelle-Calédonie par la Mission Singer-Polignac. In: Expédition française sur les récifs coralliens de la Nouvelle-Calédonie, 1960-1963, 2 : 13-28, pls. 1-3 (Editions de la Fondation Singer-Polignac, Paris).

Lindgren, N.G., 1898. Beitrag zur Kenntnis der Spongienfauna des Malayischen Archipels und der chinesischen Meere. Zool. Jb., (Syst.) 11: 283-378, pls. 17-20 (also issued separately as “Inaugural-Dissertation", Uppsala University, 1900, 96 pp.).

Muricy, G., 1989. Sponges as pollution biomonitors at Arraial do Cabo, Southeastern Brazil. Revista bras. Biol., 49 (2): 347-354.

Muricy, G., E. Hajdu, M. Custodio, M. Klatau, C. Russo \& S. Peixinho, 1991. Sponge distribution at Arraial do Cabo, SE Brazil. Coastal Zone '91. In: O.T. Magoon, H. Converse, V. Tippie, L.T. Tobin \& D. Clark (eds.), Proc. VIIth Symp. coast. Ocean Manag. (Long Beach, U.S.A., 8-12 July 1991). ASCE Publs., 2: 1183-1196.

Row, R.W.H., 1911. Report on the sponges collected by Mr. Cyril Crossland, 1904-5. Part II. Non-Calcarea. In: Reports on the marine biology of the Sudanese Red Sea, XIX. J. Linn. Soc., (Zool.) 31: 287-400, pls. 35-41.

Rützler, K., 1978. Sponges in coral reefs. In: D.R. Stoddart \& R.E. Johannes (eds.), Coral reefs: research methods. Monographs on Oceanographic Methodology, 5: 299-313 (UNESCO, Paris).

Schmidt, O., 1862. Die Spongien des Adriatischen Meeres: i-viii, 1-88, pls. I-VII (Engelmann, Leipzig).

Soest, R.W.M. van, 1981. A small collection of sponges (Porifera) from Hong Kong. In: B.S. Morton \& C.K. Tseng (eds.), Proceedings of the first international marine biological workshop: The marine flora and fauna of Hong Kong and southern China, Hong Kong, 1980: 85-95 (Hong Kong University Press, Hong Kong).

Soest, R.W.M. van, 1991. Demospongiae higher taxa classification re-examined. In: J. Reitner \& H. Keupp (eds.): Fossil and recent sponges: 54-71 (Springer-Verlag, Berlin).

Soest, R.W.M van \& N. Stentoft, 1988. Barbados deep-water sponges. Stud. Fauna Curaçao, 70 (215): 1-175.

Sollas, W.J., 1888. Report on the Tetractinellida collected by H.M.S. "Challenger", during the years 1873-1876. Rep. scient. Results Voy. Challenger, (Zool.) 25 (63): i-clxvi, 1-458, pls. I-XLIV, 1 map.

Tanita, S., 1970. Sponge-fauna of Sagami Bay, especially the Demospongiae. Bull. Tohoku reg. Fish. Res. Lab., 30: 87-97.

Tanita, S. \& T. Hoshino, 1990. The Demospongiae from Sagami Bay collected by His Majesty Emperor Showa: 1-197, pls. I-XIX (Biological Laboratory Imperial Household, Tokyo).

Thiele, J., 1899. Studien über Pazifischen Spongien. Zoologica, Stuttgart, 24 (2): 1-34, pls. I-V.

Thiele, J., 1900. Kieselschwämme von Ternate, I. Abh. senckenb. naturforsch. Ges., 25 (1): 19-80, pls. II-III.

Thiele, J., 1903. Kieselschwämme von Ternate, II. Abh. senckenb. naturforsch. Ges., 25 (4): 933-968, pl. XXVIII.

Topsent, E., 1892. Diagnoses d'Éponges nouvelles de la Méditerranée et plus particulièrement de Banyuls. Archs. Zool. exp. gén., (2) 10, Notes Revue: xvii-xxviii.

Topsent, E., 1896. Matériaux pour servir à l'étude de la faune des Spongiaires de France. Mém. Soc. zool. France, 9: $113-133$.

Topsent, E., 1898. Introduction à l'étude monographique des Monaxonides de France. Classification des Hadromerina. Archs. Zool. exp. gén., (3) 6: 91-113.

Topsent, E., 1900. Étude monographique des Spongiaires de France, III. Monaxonida (Hadromerina). Archs. Zool. exp. gén., (3) 8: 1-331, pls. I-VIII.

Topsent, E., 1904. Spongiaires des Açores. Résult. Camp. scient. Prince Albert I, 25: 1-280, pls. I-XVIII, [281-316].

Topsent, E., 1928. Spongiaires de l'Atlantique et de la Méditerranée provenant des croisières du Prince Albert Ier de Monaco. Résult. Camp. scient. Prince Albert I, 74: 1-376, pls. I-XI, [377-399].

Vacelet, J., P. Vasseur \& C. Lévi, 1976. Spongiaires de la pente externe des récifs coralliens de Tuléar (sud-ouest de Madagascar). Mém. Mus. natn. Hist. nat. Paris, (A, Zool.) 99: 1-116, pls. I-X.

Wilson, H.V., 1925. Siliceous and horny sponges collected by the U.S. Fisheries Steamer "Albatross" during the Philippine Expedition, 1907-10. Bull. U.S. natn. Mus., $100(2,4)$ : i-vii, 273-506, pls. 37-52, 507-532.

Received: 22 September 1991

Revised: 12 February 1992 